\title{
Besinning oor die interpretasie van die geloof wat in die belydenis van die maagdelike
} verwekking van Jesus geleer word ${ }^{1}$

\author{
Andries van Aarde \\ Departement Nuwe-Testamentiese Wetenskap \\ Universiteit van Pretoria
}

\begin{abstract}
Interpreting the doctrine of the virginal conception of Jesus

The aim of this article is to reflect on the hermeneutical premises related to doctrinal criticism. The dogma of the virginal conception of Jesus as recorded in the Heidelberg Catechism and the Belgic Confession serves as case study. The article argues that the same historical critical exegetical principles applied to Scripture should guide the interpretation of creeds. Christian doctrine should be seen as a social demarcator, grounded in the foundational narrative of Jesus of Nazareth. This foundational narrative is interpreted by means of doctrinal criticism when doctrine is seen as the interpretation of the experience of belief and as the articulation of truth.
\end{abstract}

\section{INLEIDENDE OPMERKINGS}

Om jou geloof te bely is ' $n$ belangrike deel van om singewend deel van die gemeenskap van gelowiges te wees. Om egter net met die verstand oor te sê wat die vroeëre geloofsgetuies bely het, sonder dat die mond oorloop waarvan die hart vandag vol is, is om nie self eg tot belydenis te kom nie. Belydenis vloei voort uit ' $n$ bewustelike belewenis van geloof en 'n eksistensiële betrokkenheid by die kerk as geloofsgemeenskap. Kerkwees veronderstel 'n dinamiese gemeenskap van gelowiges. Hierdie gemeenskap is dinamies

\footnotetext{
'Hierdie artikel is ' $n$ verwerking van 'n studie wat gedien het as besprekingspunte by die Voortgesette Teologiese Toerustingkursus van die predikante van die Nederduitsch Hervormde Kerk in Junie en November 1998 op die kampus van die Universiteit van Pretoria.
} 
by die lewe van elke dag betrokke. In die belydenis verwoord die kerk as geloofsgemeenskap dit wat die kerk glo en leer. Wanneer hierdie twee sake, glo en leer, in kombinasie voorkom, is tradisie ter sprake. Met "tradisie" word hier bedoel die oorlewering van belydenis van geloof wat geleer word. Hierdie "leer" se wortels lê in die tradisies wat opgeteken is in die Heilige Skrif en in die belydenisskrifte. Die belydenisskrifte het weer in bepaalde historiese kontekste ontstaan, net soos die tradisies in die Heilige Skrif hulle eie historiese kontekste het. Die tradisies in die Heilige Skrif is meer fundamenteel as dié in die belydenisskrifte. Die tradisies in die belydenisskrifte is veronderstel om te berus op interpretasies van dié in die Heilige Skrif. Die interpretasie van die Heilige Skrif is deel van die eksegetiese aktiwiteit in die teologiebeoefening en teologie veronderstel ' $n$ akademiese aktiwiteit.

In die Nederduitsch Hervormde Kerk word van alle gelegitimeerde predikante verwag om by wyse van die ondertekening van ' $n$ formule te verklaar dat die "leer wat uitgedruk is in" die belydenisskrifte van die kerk "onderskryf" sal word en dat predikante "oortuig is en glo" dat hierdie leer "in ooreenstemming is met die Woord van God" (Kerkorde, Ordinansie 1.1.2; kyk NHKA 1997:4). Die uitdrukking "leer in die belydenisskrifte" is die geloof wat geleer word. Alister McGrath (1990:12) vat dit soos volg saam:

\begin{abstract}
Christian doctrine may be regarded as the present outcome of that long growth of tradition in which the Christian community has struggled to arrive at an interpretation of its foundational traditions, embodied in the New Testament, which both do justice to its own present place in tradition, and attempts to eliminate those doctrinal prejudgments which are to be judged as inadequate. It is a historical phenomenon, grounded in history and conscious of its own historicity. To deal with the subject of doctrine is thus to deal with a matter which includes, but is neither restricted to nor totally dominated by, the academic study of theology.
\end{abstract}

Volgehoue instemming met die oortuiging dat wat die kerk leer in ooreenstemming is met wat in die Woord van God gevind word, vra volgehoue interpretasie van die tradisies in die Heilige Skrif en in die belydenisskrifte. Interpretasie is per definisie eietydse vertolking. Sulke arbeid is egter nie ongekompliseerd nie. Die Heilige Skrif is 
vir hervormers die normerende norm en die belydenisskrifte die afgeleide norm. Dit is waarom ons kan oorweeg om in die lig van bepaalde veranderde omstandighede nuwe belydenisskrifte op te stel. Met ander woorde, vir 'n hervormende kerk is dit altyd moontlik om nuwe belydenisskrifte op te stel. Die vraag na die wenslikheid dat dit nou weer eens moet gebeur, kan eers na ondersoek beantwoord word. Ook hierdie ondersoek is nie ongekompliseerd nie. In hierdie artikel wil ek drie sake rakende hierdie debat aanraak. Dit hou verband met (1) my siening oor die geloof wat geleer word, (2) die hermeneutiese uitgangspunte ten opsigte van die verhouding Skrifbeskouing en belydenisskrifinterpretasie en (3) enkele aantekeninge oor my interpretasie van die belydenis van die maagdelike verwekking van Jesus Christus. Wat die eerste saak betref, voel ek my in sekere opsigte tuis in die werk van Alister McGrath (1990), The genesis of doctrine: A study in the foundation of doctrinal criticism. Hoofstuk 3 van hierdie boek is getitel "The nature of doctrine: Four theses". My refleksie is 'n uitluister van McGrath se vier stellings.

\section{DIE GELOOF WAT GELEER WORD}

Geloof in God is onder andere "kennis" van God, sê die Heidelbergse Kategismus. Hierdie "kennis" vloei nie in die eerste plek voort uit wat gelowiges met hulle verstand kan begryp nie, het die hervormer, Philippus Melanchthon (kyk Schulze 1994:200-202), egter daarby gevoeg. Geloof is eerder vertroue as respons op die ontmoeting met God. Hierdie vertroue omvat die totaliteit van menswees: gevoel, verstand en handeling. Hoewel hierdie drie aspekte op die gelowige as individu betrekking het, groepeer individue hulle in ' $n$ gemeenskap as gevolg van die raakpunte wat daar is in die individuele ontmoetings met God. Die gesig van God is vir Christene sigbaar in Jesus van Nasaret. Daar is verskeie profiele van Jesus wat die "objek" van geloof is, maar daar is net én Jesus van Nasaret. Die soeke na hierdie "Jesus van die geskiedenis" is die historiese erns maak met die beginpunt van die geloof wat geleer word. McGrath (1990:35) sê: "The history of Jesus of Nazareth may be regarded as the precipitating or generative event of Christian doctrine. A community and an associated foundational narrative arose in direct response to that history, which sought to identify and legitimate both the existence of that community as a social entity and its distinctive understanding of God and human nature 
and destiny with reference to the perceived significance of Jesus of Nazareth." $\mathrm{Na}$ aanleiding van dié "beginpunt" formuleer McGrath (1990:37) vier stellings:

- Die geloof wat geleer word ("doctrine") funksioneer as 'n sosiale merker.

- Die geloof wat geleer word het voortgevloei uit 'n fundamentele narratief en interpreteer daarna hierdie narratief.

- Die geloof wat geleer word interpreteer ervaring.

- Die geloof wat geleer word bevat waarheidsaansprake.

\subsection{Eie identiteit}

Die verbintenis van Christene aan die Jesus-saak onderskei hulle van aanhangers van ander godsdienste. Uiteraard is daar baie ooreenkomste tussen godsdienste, maar die geloof dat Jesus van Nasaret die gesig van God is, maak Christene reeds van die eerste eeu $\mathrm{nC}$ anders as nie-Christene. Studies dui daarop dat in die periode na die Bar Kogbaopstand in $135 \mathrm{nC}$ die sinagoge as kultus heeltemal los van die kerk as geloofsgemeenskap begin funksioneer het (kyk Katz 1984:76). Vanaf hierdie selfde tyd het die leefwyse van Christene ten opsigte van sekere belangrike sosiale sake (insluitende godsdienstige oortuigings) duidelik van die Grieks-Romeinse leefwyse begin verskil. Dit kan veral in die literatuur van die vroeë Christelike apologete gesien word. McGrath (1990:38) verwys soos volg na die ontstaan van afsonderlike identiteite in hierdie tyd: "There is a perceived need for a theological justification of the separation of the Christian church from its Jewish matrix, and subsequently in justifying its distinction from the Hellenism of the patristic period. Doctrine is thus linked with the affirmation of the need for certain identitygiving parameters for the community, providing ideological justification for its continued existence."

Die proses van die vorming van eie identiteit het reeds in die eerste eeu $\mathrm{nC}$ plaasgevind en die spore daarvan kan in literatuur van die vroeë Christene (soos o a in die Nuwe Testament) gesien word. Van die interessante aanduidings hiervan is die wyse waarop die volgelinge van Jesus titels vir Jesus gegee het wat nie net vertel watter persepsie hulle van Jesus gehad het nie, maar ook hoe hulle Jesus onderskei het van die messiaanse figure in die kontemporêre Palestynse geskiedenis asook van "wetgewers" en 
"priesters" wat as meestersimbole gedien het (bv Moses en Melgisedek). Terselfdertyd onderskei die Christologiese titels Jesus en die kultus van Christene van die aanbiddingspatrone in die Grieks-Romeinse sosiale wêreld. Die mitiese vertellings in die evangelies oor Jesus se geboorte, natuurwonders, opstanding en hemelvaart is ook identiteitsmerkers wat openbaar wat Christene geglo en geleer het in onderskeid met die oortuigings van tradisionele Israel en dié van die Hellenisme.

Die geloof wat geleer word, het vanaf die vierde eeu $\mathrm{nC}$ nie net as identiteitsmerker gefunksioneer om die kerk van Judaïsme and Romeinse keiserkultus te onderskei nie, maar ook om ortodoksie van heterodoksie binne die kerk te skei. McGrath (1990:41) verwys soos volg hierna:

\begin{abstract}
With the conversion of Constantine, Christianity assumed a new status within the Roman Empire, and doctrinal formulations became of increasing political importance...With the imperial resolutions of the Arian crisis, "doctrine" rapidly assumed the character of legally sanctioned ideology - a concept perhaps accurately designated "dogma". The relative pluralism of an earlier understanding of doctrine (that is, of a central core of ideas, and agreement concerning the texts to be used in teaching, preaching and theological exploration) reflected the unintegrated social structure of the Christian church of the period; with the advent of centralization during the Constantinian period came the idea of the church as a single institutional unit, requiring doctrinal uniformity in order to preserve its new-found social function and status.
\end{abstract}

\title{
2.2 Die fundamentele narratief
}

'n Kritiese besinning oor hierdie nuwe rol wat geloofsbelydenis begin inneem het, bring 'n mens uit by die tweede stelling, naamlik dat die geloof wat geleer word voortgevloei het uit 'n fundamentele narratief, maar dat dit ook daarna as kriterium begin funksioneer het waarolgens hierdie narratief geïnterpreteer is. As daar in vandag se toenemende postmoderne tyd gepoog word om "geloof wat geleer word" bloot kognitief te analiseer en om slegs te beskryf hoe die voorgeslag geglo en hulle geloof verwoord het, sal al hoe meer mense met ontsteltenis dink dat hulle God verloor het. Daar is mense wat oënskynlik hierdie verlies gelate aanvaar en met sekularisasie as leefwyse vrede gemaak 
het. Daar is egter ook mense wat hulp soek by mense wat die geloof in God lewe. Wat kan 'n mens vir hulle sê? Vertel hulle van en herinner hulle aan die "fundamentele storie" van die vroegste Christene se geloof. Dit is die storie van Jesus van Nasaret. Dit is 'n storie wat vertel dat geloof iets is soos ' $n$ innerlike gevoel van diep afhanklikheid van en sterk vertroue in God. Hierdie storie word gevind in die stories van die Nuwe Testament en die stories van die Nuwe Testament het as dekor veral die OuTestamentiese stories oor die suksesse en mislukkings van mense wat God gesoek, gevind of verloor het. Die belydenisse van die geloofgemeenskap behoort verwoordings van hierdie afhanklikheid en vertroue te wees. Die "fundamentele narratief" is die maatstok aan die hand waarvan Skrif en belydenisskrifte krities vir evangeliese waardes ontgin word. Die "fundamentele narratief" van Christene behoort die model te wees van wat die sin van geloof in God kan wees. Mense soek rolmodelle. Die vertellers van hierdie narratief kan rolmodelle wees as hulle hulle geloof leef. Die lewe van geloof vind plaas binne die geloofgemeenskap. Kerkwees behoort hierdie gemeenskap te wees, maar die gemeenskap van geloof sal in 'n gesekulariseerde wêreld ook buite die institusionele kerk om kan plaasvind.

Volgens beriggewing in koerante en opinievormende tydskrifte lyk dit op grond van die groot reaksie in die korrespondensierubrieke van hierdie koerante en tydskrifte dat die stem van Christene in die breë gesekulariseerde samelewing steeds graag deur die publiek gehoor wil word. Die feit dat die uitsprake van die kerk as instituut egter grotendeels geïgnoreer word, dui op 'n proses van de-institusionalisering. Hierdie proses is egter net weer die begin van 'n nuwe spiraal van her-institusionalisering. Is daar vir die kerk as sodanig ruimte in hierdie nuwe proses of stuur die postmoderne wêreld onverbiddelik af op 'n post-kerklike samelewing? Binne die proses van globalisasie en binne die vestigende nuwe mondiale kultuur lyk dit asof daar vir die kerk as hergestruktureerde instituut in 'n sekere sin plek in die onmiddellike toekoms sal wees as die kerk ekumenies diensbaar is. Daarom sal die kerk as dinamiese geloofsgemeenskap met visie en missie moet deelneem aan die nuwe institusionaliseringsproses. In sulke omstandighede is die modernistiese rasionele benadering tot die "geloof wat geleer word" agterhaal. 'n Subversiewe houding tot die kognitiewe oorbeklemtoning van die rol van dogmas in kerk as geloofsgemeenskap het deel van die hedendaagse tydsgees geword. 
Elke nuwe proses van institusionalisering het 'n charismatiese vertrekpunt. Charisma kan hier verwys na individue (en nie die kerk as instituut nie) wat met die visie en die missie vorendag kom wat deur 'n groter groep as bevrydend van stagnerende en irrelevante strukture, geloofspatrone en kulturele konvensies ervaar en nagevolg word. Charisma kan ook teologies verstaan word as dit verwys na hierdie "entrepeneurs" as mense wat gevoelig vir God se stem is. Maar dit is ook die tyd dat ons bewus word van die vraag na die onderskeid tussen "ware" en "valse" profete. In die kerk behoort daar kerkordelik ruimte gebied te word vir die akkommodering van die verskillende stemme wat in hierdie proses gehoor word. Die gesprek van "profete" moet nie geïnhibeer word en daar moet nie te gou deur gesagsfigure besluit word oor watter stem is eg en watter stem is vals nie. Ons bevind ons waarskynlik in die tweede fase van die nuwe institusionaliseringsproses (kyk Tuckman 1965:384-399). Die eerste fase was dié toe daar individue vorendag gekom het wat oor die alternatiewe visie begin praat het. Die tweede fase waarin die kerk nou ingaan, is nog nie dié van formalisering nie, maar van "storming" wat die tyd van hewige debat is. Eers hierna volg die fase van die uitkristallisering van nuwe "norme" en "kodes". Diegene in die kerk wat hulle in enklaves van die proses van die "institusionalisering van charismatiese gesag" onttrek, oefen die apokaliptiese keuse van selfgekose marginalisering uit.

Die "fundamentele narratief" vertel die verhaal van Jesus as "charismatiese figuur". Op grond van die oorlewering van hierdie narratief deur sy volgelinge het Jesus indirek 'n proses van her-institusionalisering ingelei. Die Duitse sosioloog Max Weber ([1947]1968:246-254) het na hierdie proses verwys as die "Veralltăglichung des Charisma” (kyk Lemmen 1990:137-145; Mödritzer 1994:277-284). Die Nuwe-Testamentikus, Bengt Holmberg (1978), het die oorlewering van die teologiese visie van Paulus in die deutero-Pauliniese briewe deur mense wat deur Paulus beïnvloed is, aan die hand van Weber se sosiologiese teorie ondersoek. Holmberg (1978:162-195) het na die deuteroPauliniese getuienis van die "institusionaliseringsproses" van die vroeg-katolieke kerk (kyk Käsemann 1963:75-89) verwys as die "institusionalisering van charismatiese gesag”. Die Nuwe-Testamentikus wat bekend is vir sy publikasies oor die prinsipes van die hermeneutiek, Anthony Thiselton $(1980,1992)$, het voorgestel dat Weber se teorie ook toegepas word op die Christologiese ondersoek na die oorgang van die "historiese 
Jesus" na die "kerugmatiese Christus" (kyk Thiselton 1994:453-472; vgl Ellingworth 1994:497). In Suid-Afrika het Yolanda Dreyer (2000) 'n PhD-proefskrif in die NuweTestamentiese Wetenskap oor hierdie onderwerp geskryf. Haar studie is getitel "Institutionalization of authority and titles used for Jesus".

Die proses van die "institusionalisering van charismatiese gesag" het daartoe gelei dat volgelinge van Jesus binne 'n verskeidenheid van na-Pase Jesus-bewegings (kyk Crossan 1998:415) ' $n$ eie identiteit begin aanneem het. Indien die kerk se selfverstaan vandag steeds gevorm word op grond van 'n ontmoeting met die tradisies wat gebaseer word op die "fundamentele narratief", kan die kerk myns insiens singewend die een en twintigste eeu ingaan. Hierdie narratief het as verwysingspunt die "wysheid" van Jesus van Nasaret. Jesus se "wysheid" was 'n alternatief op die konvensionele eerste-eeuse wysheid van Israel (kyk Borg 1991:15).

In die Oud-Oosterse wysheidsliteratuur is die insig in die mens as kulturele wese in verhouding met God en medemens hokma genoem. Loader (1979:97-98) verwys daarna as Lebenskunde. Wysheid is om harmonieus by God se skeppingsorde in te pas, wysheid is respek/vrees vir God en die orde wat geglo is deur God daargestel is. Dit is 'n orde waar alles en almal hulle plek, tyd en rol het: 'n orde van eer en skande, 'n orde waar mans, vrouens en kinders hulle onderskeie regte en voorregte het, 'n orde van herkoms en geboorte, van Leviet en Israeliet, van Leviet, priester en Samaritaan, van besnedene en heiden, van heilig en onheilig, van rein en onrein; 'n orde waarvolgens daar in hierdie lewe (of, soos later op grond van die apokaliptiek gedink is, by dood of by die opstanding vanuit die dood) beloon of gestraf word. Hierdie wysheid toon 'n ontwikkelingstrajek in vorm en inhoud (vgl Loader 1979:120-123): van spreukagtige aforismes (bv die boek Spreuke) tot verhale (bv Job) tot diskoerse van opponerende gedagtes (bv Prediker); van gedragsreëls tot personifiërende taal, tot die identifikasie met die konsep "wet van God". Laasgenoemde, die sogenoemde "tora-wysheid", kom na vore in die Wysheid van Jesus die seun van Sirag, die Wysheid van Salomo en laastens in die Rabbynse Fariseïsme se kulturele stratifikasie met betrekking tot mense, plekke en dinge ten opsigte van ' $n$ hiërargiese klassifikasie in terme van heilig tot minder heilig, tot onheilig (kyk Douglas 1966; Neusner 1973; Neyrey 1990:24-31). 
Navorsing deur veral Schmid $(1966,1968,1973)$ toon ooreenkomste in OudOosterse (Egiptiese, Mesopotamiese en Israelitiese) wysheidsliteratuur wat dui op 'n bepaalde ontwikkelingstrajek in die wyse waarop die begrip "wysheid" funksioneer. Aanvanklik is wysheid die preëksistente "krag" en "beeld" van God wat wêreldstigtend en wêreldordenend funksioneer. Later kry dit 'n antropologiese funksie en funksioneer dit personifiërend as verwysende na God se onderskeidingsprinsiep in sosio-religieuse etiek waarvolgens daar tussen "regverdiges" (die wyses) en goddeloses (die dwases) onderskei word. In hierdie onderskeiding figureer die oud-Oosterse regsbeginsel dat dade en gevolge in samehang bestaan: God straf die goddelose en beloon die regverdige. Ten slotte neem wysheid die vorm aan van kritiese wysheid wat gerig is teen dié vergeldingsidee.

Crenshaw (1981) en Witherington (1994) voer onderskeidelik hierdie trajek verder deur ook wysheidspsalms $(19,62,94,37,73,49)$, die Wysheid van Jesus seun van Sirag, die Wysheid van Salomo, Barug 3-4 en 1 Esra 3-5 asook die Nuwe Testament in ag te neem. Dit was veral die Wysheid van Ben-Sirag (ongeveer $180 \mathrm{vC}$ ) wat met behulp van die Mosaiëse wet as Goddelike wysheid die konvensionele wysheid se vergeldingsidee (hoewel uitgestel) in stand wou hou. Witherington (1994:115) wys daarop dat hoewel Spreuke 2:6, Ben-Sirag 1:9-10, 26; 6:37 en die Wysheid van Salomo 7:7; 9:4 wysheid sien as 'n gawe van God, dit steeds alleen deur inspanning in terme van die daad-gevolg-samehang verkry kan word (Spreuke 4:10-27; 6:6, Ben-Sirag 4:17; 6:18-36 en WyshSal 1:5; 7:14). Verder is dit opvallend dat Semities-Hellenistiese literatuur (soos Ben-Sirag 24:8-12) wysheid as Goddelike ordeningsprinsiep alleen met Israel geassosieerd sien ( $\mathrm{vgl}$ cok WyshSal 10:1-21). Dit is eweneens in hierdie literatuur dat wysheid met tora geïndentifiseer word (Ben-Sirag 24:23; vgl ook Ben-Sirag 1:25-27; 6:37; 15:1; 19:20; 33:2-3; Barug 4:1).

Die vorm en inhoud van Jesus se onderrig toon dat Hy 'n wysheidsleraar was in terme van die ontwikkelingstrajek wat in die Oud-Oosterse wysheidsliteratuur te onderskei is. Sy leringe was mondeling van aard en het bestaan uit kort metaforiese vertellings (gelykenisse) en skerp "een-lyn" aforismes (kyk Funk \& Hoover 1993:30-34). Die strekking in beide tipe vorms was "skokkend" en het die hoorders uitgelok tot nuwe persepsies oor ou konvensionele kultuuropvattings (kyk Borg [1994] 1995:88-117). 
Laasgenoemde is voorgestel as onder andere die "breë weg" teenoor die nuwe as die "nou weg". Jesus se "alternatiewe wysheid" het 'n gans andere voorstelling gebied as die konvensionele oor die rol van die kultus, oor wat rein en onrein is, oor Leviet, priester en Samaritaan, oor by wie God teenwoordig is, oor vrouens en kinders, heidene en uitgestotenes. Dit was in tweërlei opsigte nie heeltemal uniek nie: dit het aangesluit by enersyds die kritiek in die boeke Job en Prediker teen die "vergeldingsdogma" van 'n oog om 'n oog en andersyds by die profetiese kritiek teen die onreg wat hooggeplaastes teen geringes pleeg. Dit was in tweèrlei opsigte wel uniek deurdat dit enersyds die indirekte bemiddeling deur middel van die versoeningshandelinge in die kultus deur die priesters en die offerritueel waardeur die mens in die regte verhouding met God gestel kon word, ontken het en andersyds die nasionale en patriargale voorkeure bevraagteken het. Dit was nie apokalipties-kataklismies van aard nie en het die moontlikheid van waaragtige en sinvolle lewe hír en nóú verkondig.

Teen hierdie agtergrond illustreer die volgende lang aanhaling uit die werk van Alister McGrath (1990:54-55) die stelling dat die geloof wat in die geloofsgemeenskap geleer word voortvloei uit die "fundamentele narratief", maar dat dit ook hierdie narratief interpreteer:

[T] he character of the Christian community arises from its historical derivation from the precipitating event of Jesus of Nazareth, and a willingness to let his story govern that community's understanding of its his historical situation and future: its attitudes to power, to pride, to loss, to death, to grief, to despair - all are governed by the narrative of Jesus of Nazareth. "Jesus" assumes a role within the community of faith ... [that] evokes a deep sense of "happening", the memory of a foundational narrative and its present significance for the community whose identity is inextricably bound up with it. It provides a focus of identity for the community. The New Testament affirmation of the conformity of the believer to Christ - that, through faith, those who believe in Christ are somehow caught up in him, so that his history becomes their history - provides a significant theological foundation for this correlation of narratives. His death is their death, his life is their life - and the narrative of Jesus gives some specification to Christian existence by aligning that existence with lived life, with a specific historical person ... The narrative of 
Jesus is thus interpreted as a story which grounds Christian existence, which gives some shape and specification to what human outlooks on life, what form of actions, enabling us to avoid thinking Christianity in terms of universal abstractions, and instead to ground it in the contingencies of our historical existence.

\subsection{Ervaring en waarheid}

Die laaste twee stellings waarna hierbo verwys is, te wete dat die geloof wat geleer word, ervaring interpreteer en dat dit aansprake van waarheid bevat, kan in samehang bespreek word teen die agtergrond van my uiteensetting van Christene se fundamentele narratief. Waarheid in die Nuwe Testament en Ou Testament hou verband met die gelowige se ervaring van God se barmhartigheid wat uit God se geregtigheid voortvloei. Latynse vertalers van Griekse tekste (soos die Septuagint en Nuwe Testament) het die woord "veritas" gebruik om die woord alétheia (á $\lambda \eta^{\prime} \theta \varepsilon ı$ ) te vertaal. In die Ou Testament is hierdie Griekse woord weer 'n vertalingsekwivalent van 'n aantal woorde (bv emet [אמת]] en emunah [אמונה] - kyk Quell 1933:233-237) wat opvallend dikwels binne die konteks van aangeleenthede soos geregtigheid (kyk Ps 15:2; 45:5; Jer 5:1; Am 5:10; Jes 59:14; Sag 8:16) en barmhartigheid (kyk Gen 47:29) gebruik is.

Wanneer ' $n$ mens die gebruik van die woord "waarheid" by Johannes en Paulus nagaan, kan ' $n$ mens van hierdie twee Bybelskrywers as 't ware 'n sistematiserende gedagtekonstruk aflei. Rudolf Bultmann (1933:242-251) het op grond van die voorkoms van die woord "waarheid" by hierdie twee Nuwe-Testamentiese skrywers 'n konstruk daargestel en dit vir ons in Gerhard Kittel se bekende Theologisches Wörterbuch zum Neuen Testaments beskryf. Bultmann se student, Ernst Fuchs (1962:1515-1517), het hierdie gedagtekonstruk besonder kompak en duidelik in die Religion in Geschichte und Gegenwart (Sechster Band) weergegee. Uiteraard is 'n waarheidsbeskouing ook vanuit gedeeltes in die Corpus Paulinum en die Johannese literatuur af te lei waar die woord "waarheid" nie self eksplisiet voorkom nie. Ons moet egter nie Bultmann en Fuchs (ofte wel Paulus of Johannes) se beskouing oor "waarheid" as 'n "proposisionele waarheid" opneem nie. McGrath (1990:62) maak die belangrike opmerking: "The primary literary form encountered within scripture is that of narrative, rather than propositional formulation, suggesting that the appropriate mode of analysis is inference rather than 
deduction. In that scripture recounts a narrative, a set of particularities, a process of inferential, rather than deductive, analysis is clearly indicated. The question concerns what framework of conceptualities may be inferred from this narrative."

Dit was duidelik nie Paulus of Johannes (en ook nie Bultmann of Fuchs wat eksistensieel met hulle instemming betoon het) se bedoeling om hulle verstaan van wat "waarheid" is, gelyk te stel met objektiewe, waarneembare en kontroleerbare proposisionele synskategorieer nie. Waarheid vertel volgens hulle 'n storie. Die bekende Pilatusvraag in Johannes 18:38, "Wat is die waarheid?", dui vir ons die rigting aan om "waarheid" hier níe in die sin van proposisionele formules te verstaan nie. Sulke formules veronderstel iets wat hoofsaaklik met die verstand begrypbaar en uitgelê word. Volgens Johannes kon Piliatus juis nie die getuienis wat Jesus voor hom gelewer het, met kontroleerbare, waarneembare objektiwiteit versoen nie! Die vierde evangelis laat Jesus in Joh 18:37b oor Homself sê: "Dit is soos u sê: Ek is 'n koning," ... "Ek moet oor die waarheid getuienis aflê. Hiervoor is ek gebore, en hiervoor het Ek na die wêreld toe gekom. Elkeen wat aan die waarheid behoort, luister na wat Ek sê." Hierdie uitspraak is in ' $n$ sekere sin ' $n$ herhalende teruggrype na wat die verteller in die Johannes-evangelie in Joh 1:14 self getuig het: "Die Woord/Logos het mens geword en onder ons kom woon. Ons het sy heerlikheid gesien, die heerlikheid wat $\mathrm{Hy}$, as die enigste Seun, van die Vader het, vol genade en waarheid." In sy getuienis voor Pilatus laat die verteller vir Jesus self getuig: "My koninkryk is nie van hierdie wêreld nie" (Joh 18:36a). Vroeër in die vertelling, in Johannes 14:6, sê Jesus: "Ek is die weg en die waarheid en die lewe. Niemand kom na die vader toe behalwe deur My nie." 'n Subjek, 'n persoon, Jesus, word die "waarheid" genoem. Dit is nie 'n "subjektiewe proposisie" wat as "waar" beskou word nie, maar die subjek self én die saak/getuenis waarvoor hierdie subjek gestaan het. Waarskynlik word daar van ons verwag om rondom die saak van Jesus iets in te vul, sodat ons kan uitkom by iets wat "waarheid" genoem kan word. Dit is waarom Rudolf Bultmann 'n hele gedagtekonstruk na aanleiding van die gebruik van die woord "waarheid" by Johannes (en Paulus) daar kon stel. Dit is die Jesus-saak wat as "waarheid" gesien moet word. Hierdie proposisie is allén vanuit die perspektief van die geloof "waar" en nie omdat dit as empiries "waar" bewys kan word nie. Wie sou nou ooit kan beweer dat die koninkryk waarvan Jesus gepraat het, in waarneembare terme 
ooreenkom met die tipe koninkryke wat Pilatus rondom hom gesien, ervaar en verteenwoordig het?! Dit wil lyk asof die vierde evangelis vir ons wil sê dat ons moet kies wat ons as "waarheid" wil huldig: of die waardes van die keiser van Rome soos gemanifesteer in sy koninkryk, of die waardes van die Koninkryk van God soos gemanifesteer in die saak van Jesus.

So gesien, kom ons, wanneer ons met "waarheid" te doen het, voor 'n ultimatum te staan. Hierdie Latynse superlatief bring ons uit by wat in filosofiese sin "waarheid" genoem word, naamlik dit wat as die hoogste waarde, die ultimate, vir die mens gereken word. As gevolg van die invloed van die Griekse denke is die "hoogste waarde" metafisies verstaan. Wat die metafisika betref, word daar sedert Plato (c 427 - c $347 \mathrm{vC}$ ) 'n onderskeid getref tussen "natuurlik" en "bo-natuurlik", tussen "menslik" en "goddelik". In die leefwêreld van die Bybel het mense egter nie as sodanig 'n onderskeid tussen 'n "bo-natuurlike" verskynsel (bv 'n beriggewing dat die Gees van God iemand in besit sal neem of met iemand iets te doen sal hê) en 'n "natuurlike" verskynsel (bv die geboorte of dood van iemand, reën, weerlig of aardbewing) getref nie. Die primêre onderskeid in hierdie verband was eerder tussen "skepper" en "skepping". Laasgenoemde het nie net betrekking op die sogenaamde "natuurlike" dinge (soos menslikheid en die dinge waarmee mense in aanraking kom) nie, maar ook op die sogenaamde "geestelike" dinge wat met die godewêreld te doen het (soos engele, demone, wonders, wonderdoeners en magie). Hierdie "spirituele" ervarings staan met ander woorde nie los van of bo die "natuurlike" dinge nie, maar is daarmee ineengevleg. In die teologiegeskiedenis van die Christendom in die Weste vind ons dat die kategorie "bo-natuurlikheid" eers 'n betekenisvolle rol begin speel het toe die werke van die vyfde-ceuse Pseudo-Dionisios gedurende die negende eeu in Latyn vertaal is (kyk Saler 1977:31-53).

As gevolg van Plato se invloed is die metafisika ontologies verstaan. Ontologiesmetafisiese denke het te doen met die Platoniese siening dat die "ware" essensie/syn van iets of iemand uitmond in die verhouding van die persoon of ding met of tot wat as die ultimate beskryf kan word. In Platoniese konteks is die konsep ultimate moeilik definieerbaar. Dit het betrekking op die "hoogste", nie-materiêle realiteit wat ook beskryf kan word as die onsigbare idee wat agter die kenbare en waarneembare materiěle verskyning aanwesig is. Aanvanklik het dit betrekking gehad op "skepper" en "skep- 
ping", maar dit het toenemend uitgemond in die onderskeid en relasie tussen die "bonatuurlike" en die "natuurlike", tussen die "goddelike" en die "menslike". Om die byvoeglike naamwoord "onties" aan iemand of iets toe te skryf, is om derhalwe te verwys na 'n bepaalde synsverhouding eerder as na 'n bepaalde gedrag of funksie. Ontologie is die nadenke (beskrywing en verduideliking) van die verhouding van syn tot syn, van wese tot wese, en wel in terme van die vraag na die hoogste goed (die ultimate). Die byvoeglike naamwoord vere in die bekende Christologiese formule van die Chalcedonkonsilie, vere homo...vere Deus (waaragtige mens ... waaragtige God), sal dan verwys na die persoon/syn van Jesus wat ten volle ooreenstem met die syn van menswees én met die syn van God as transendentale geestelike wese.

Die Jesus-saak as die "waarheid" (dit wil sê, as die "hoogste waarde"/ultimate) word egter nie in die Nuwe Testament in ontologies-metafisiese terme beskryf nie. Dit sluit ook die Johannes-evangelie in wat teen die einde van die eerste eeu ontstaan het (vgl McGrath 1990:62). In Joh 1:1 lees ons dat die Logos by God was en self ook God is. Ons tref hier egter nie die tipiese ontologies-metafisiese skema aan nie, maar eerder 'n "funksionele" wyse van spreke oor hoe Jesus se "gedrag" en "funksie" verstaan is. Die konsep "Logos" het ontstaan in die konteks van die sogenoemde Grieks-Semitiese wysheidspekulasie en gnostiek (hoewel die gnostiek in die Johannes-evangelie minder doseties voorgestel word). God se ontmoeting met die mens word beskryf deur middel van die konsep Logos. Hierdie uitdrukking beskryf Jesus se "ontmoetingsfunksie": vanuit die "hemelse wêreld" tree die Skeppergod die kosmos binne en tree die kosmos met liefde tegemoet. Johannes staan die (gnostiese) idee teë dat God nie met verganklike materie/syn bemoeienis maak nie. Inteendeel, volgens Johannes (en Paulus) het God se Seun mens (in alle opsigte van die syn van menswees en menslike omstandighede $-d w$ $s$ in ontologies-funksionele en nie in ontologies-metafisiese sin nie) geword. Johannes praat daarom van die "twee oorspronge" van al God se kinders: "(A)an almal wat Hom [Jesus] aangeneem het, dié wat in Hom glo, het Hy [Jesus] die reg gegee om kinders van God te word. Hulle is dit nie van nature nie, nie deur die drang van 'n mens of die besluit van 'n man nie, maar God is hulle Vader" (Joh 1:13). Op dieselfde wyse praat Johannes van fisiese brood en geestelike brood asook fisiese water en geestelike water. Dit beteken dat mense paradoksaal, hoewel hulle op 'n "menslike" wyse gebore is, as geestelike 
mense ook 'n "geestelike geboorte" het. Volgens Johannes geld dit vir Jesus op 'n besondere wyse méér as vir ander. Jesus is die "eersgeborene" van die Vader wat die naaste aan die Vader is (kyk Joh 1:18).

Ook by Paulus (Filemon 16) vind ons die gedagte dat die kind van God nie net 'n menslike natuur het nie, maar ook 'n geestelike natuur. Weer eens het ons met 'n ultimatum te make: kies - watter van dié twee bestaanswyses bied vir jou die hoogste waarde. As ' $n$ mens in ag neem dat die lewe wat deur die Gees beheers word, selflose dien (liefde) vir God en Ander inhou - dit wil sê die rugdraai op jouself om die geluk buite jouself in ontmoeting met God en Ander (in en deur die deelhê aan die Jesus-saak) te vind - lyk die keuse tussen "vlees" en "Gees" na 'n beslissing wat vertroue op objekte (insluitende die "waarde" van die self, bedoelende jou geborgenheid in die "waardes" van waarneembare dinge soos fisiese herkoms, familie, land, nasionaliteit, aardse koninkryk) verplaas na geloof in wat geen objek is nie, maar Gees. Die "Gees" beteken hier die "Here" (vgl 2 Kor 3:17a). Bevry van jouself beteken om van die bestaanswyse/syn van jou eie beperktheid, gebondenheid, eindigheid, verlos te wees - dit is ware vryheid, want "waar die Gees van die Here is, is daar vryheid" (2 Kor 3:17b). In 2 Kor 11:10 skryf Paulus: "Hierop is ek trots, en so seker as die waarheid van Christus in my is, sal niemand ... my dit [Paulus se selflose liefde vir Ander] ontneem nie." Hier vind ons 'n subversiewe benadering tot die kulturele konvensie van 'n $00 \mathrm{~g}$ om 'n oog wat onder andere neerkom op die selfhandhawing van die verganklike bestaanswyse/syn deur nie net goed te doen aan ander as hulle weer dieselfde aan jou kan doen nie (vgl ook die Jesus-uitspraak in die Spreuke-evangelie Q, soos dit weergegee is in Luk 6:27-28, 32-36 en in Matt 6:43-48). Vanuit die perspektief van 'n "vleeslike" bestaanswyse (wat in sigself eindig, verganklik en van verbygaande aard is) kom só 'n lewe op dwaasheid neer omdat dit binne die konteks van 'n harde kompeterende wêreld 'n keuse veronderstel om swak in plaas van sterk te wees.

Vir Paulus is waarheid egter die deelhê aan die Jesus-saak waarvolgens gelowiges sterk is wanneer hulle swak is (kyk 2 Kor 12:9-10). Natuurlikerwys maak mense nie só 'n keuse nie; só 'n "geestelike" bestaanwyse is 'n gawe (genade) van God. Waar die Gees van God gelowiges bemagtig, funksioneer hulle as "nuwe skepsels" binne 'n nuwe bestaanswyse, begenadig en bevry van die syn van eindigheid. Die grond vir hierdie 
paradoksale genade vind Paulus in die verkondiging van die kruisiging van die mens Jesus en die opstanding van Jesus as Seun van God (vgl ook Rom 1:3-4): "(W)ant al is Hy gekruisig in die swakheid van 'n mens, Hy leef uit die krag van God. En in Hom is ons ook swak, maar saam met Hom sal ons uit die krag van God lewe. Dit sal julle sien. Stel julleself op die proef en ondersoek julleself of julle in die geloof lewe" (2 Kor 13:45a). Om gelowig te lewe is vir Paulus om weer en weer voor die ultimatum te staan te kom: sterf saam met Christus as jy wil lewe! Hierdie radikale eis herinner aan 'n Jesusstelling wat op verskillende maniere in die evangelietradisie deur onafhanklike meervoudige getuienisse oorgelewer is. Weergawes van hierdie subversiewe uitspraak word aangetref in Lukas 17:33 en Matteus 10:39 (wat hulle inligting uit die Spreuke-evangelie Q kry), asook in Markus 8:35 (wat in Matt 16:25 en Luk 9:24 oorgeneem is) en in Johannes 12:25.

Om die gedagtekonstruk van Paulus en Johannes oor wat waarheid is, saam te vat: Christene ervaar God se teenwoordigheid op grond van hulle deel he aan/ontmoeting met Jesus, Seun van God. Die retoriek van die Johannesevangelie kan in terme van hierdie dinkraamwerk beskryf word. Die lesers/hoorders van die evangelie word oorreed om nie hulle hoogste vertroue te plaas op Jesus wat volgens die tradisie die (fisiese) seun van Josef is nie, maar om hulle geloof te grond in Jesus, die (geestelike) Seun van God (kyk Joh 6:37-40; 20:30b) want nie "gewone brood" nie, maar die "brood wat uit die hemel kom, gee aan die wêreld lewe" (Joh 6:33). Wie ook al Jesus só "sien", "sien" die "Vader" (Joh 14:9). Die klaarblyklike bedoeling van só 'n retoriek (wat moontlik in terme van die Platoniese filosofie en gnostiek geformuleer is) kon wees dat die empirieswaarneembare menswees van Jesus nie gesien moet word as 'n struikelblok om God se teenwoordigheid te ervaar wanneer die Jesus-getuienis verkondig word nie. Die gnostiek wat deur die Platoniese filosofie beïnvloed is, het geleer dat die goddelike essensie van bestaan nie in die materieel-sigbare skepping geleë is nie, maar in die "geestelike/ pneumatiese idee" agter die materie wat nie met die fisiese oog waarneembaar is nie. Volgens die Johannesevangelie sê die opgestane Jesus (wat nie deur tyd of ruimte gebind word nie - kyk Joh 20:26): "Gelukkig is dié wat nie gesien het nie, en tog glo" (Joh 20:29b). 'n Soortgelyke gedagte word by Paulus en in die na-Pauliniese briewe angetref. Waarheid is "waarheid wat in Jesus is" (Ef 4:20 - kyk Schlier 1957:221-222). Dit is 
om die waardevolle wat daar moontlik in die verganklike eindigheid van die skepping kan wees, nie meer as van waarde te ag nie (kyk Fil 3:7-11). Waarheid moet gesoek word in die transendentale. Hoewel dit vir die wêreld op dwaasheid neerkom, is Jesus die wysheid/waarheid van God.

Die feit dat die belydenis van geloof die ervaring van coram Deo verwoord en daarom aansprake van waarheid bevat, bring ons ten slotte uit by die insig dat die geloof wat geleer word, ook deur beeldspraak, ofte wel metaforisiteit, betuig kan word. Waar 'n "proposisionele waarheidsbeskouing" gemeen het om op stelligheid (omdat dit met die sg "werklikheid" ooreenkom) aanspraak te maak, dwing die erns maak met mites en metafore die teoloog om die geloof wat geleer word te sien as verbind aan 'n fundamentele narratief waarvan die interpretasie 'n oop-einde het, want dit is relatief, relasioneel en voorlopig. Soms kom hierdie fundamentele narratief voor in mites en legendes en soms in metafore soos "nuwe skepping" en ander kere in argumentatiewe redevoerings soos die Pauliniese diatribe. Soms word dit in proposisies verwoord soos in belydenisse. Wanneer dit in dogmas uitmond, moet daar krities gewaak word dat die "dogmatiese proposisie" nie die relasionele ontmoeting met God verdring en self die objek van geloof word nie. As dit gebeur, het feilbaarheid "waarheid" geword, terwyl die "waarheid wat daar in Jesus is" volgens Friedrich Schleiermacher ([1806] [1827] 1843:518, 521) iets anders wil sê: oneindigheid is die waarheid van die menslike natuur en die menslike natuur is die werklikheid waarbinne oneindigheid manifesteer (kyk Van Aarde 1999a:2527).

\section{HERMENEUTIESE UITGANGSPUNTE}

$\mathrm{Na}$ die voorafgaande prinsipiële besinning kan daar nou oorgegaan word om na te dink oor wat die interpretasie van die geloof wat geleer word behels. Die bedoelings van die Skriftuurlike getuienisse en bestaande belydenisformules behoort op ' $n$ verantwoorde hermeneutiese wyse vanuit hulle historiese kontekste ontgin te word. In die lig van hierdie geabstraheerde bedoelings behoort die vrae van ons eie tyd gelowig en verantwoordelik geïnterpreteer te word. Hierdie interpretasie geskied nie alleen ter wille van kennisverwerwing nie, maar dien die kerk sodat ons met skoon gewete voor God en in die regte verhouding met ons medemense kan lewe. 
Die uitdrukkings in die Bybel en in die belydenisskrifte is nie vaste, fundamentele entiteite na vorm en na inhoud, sodat dit net so in ons tyd geld nie. Die verskil in tydraamwerk tussen die skryf van die verskillende geskrifte in die Bybel en die onderskeie belydenisskrifte vereis interpretasie. Die teoloog behoort bewustelik in ag te neem dat die wêreldbeeld van die Bybelskrywers en die opstellers van die belydenisskrifte invloed op hulle getuienis uitgeoefen het en dat dié wêreldbeeld vandag nie meer die gangbare is nie. Vir teoloë in die hervormde tradisie behoort dit nie as bedreigend vir hulle Reformatoriese identiteit beleef te word wanneer hulle uitgedaag word om die vraag na die moontlikheid en die wenslikheid van eietydse belydenis-formules ernstig op te neem nie. Die opstel van nuwe belydenisformules sal ook nie noodwendig die bestaande belydenisskrifte vervang nie. Die geskiedenis leer dat nuwe formules of in die bestaande opgeneem word of daarnaas funksioneer. Die vorming van nuwe belydenisskrifte hoef dus nie as ondermyning van die bestaande gesien te word nie. Eksegetiese bevindings en teologiese insigte kan wel vandag anders geformuleer word as vroeër. Hierdie erkenning lei egter nie tot die ontkenning van die volgehoue belang van bestaande belydenisskrifte nie.

Die belydenisskrifte behoort in alle opsigte op dieselfde wyse eksegeties benader te word as wat die Bybel uitgelê word. Met ander woorde, die blootlegging van die historiese konteks van die geloof wat in die belydenisskrifte geleer word, sal beslis ' $n$ rol in belydenisskrif interpretasie speel. Die verwoordings in die belydenisskrifte hoef nie gesien te word as dogmas wat oor tyd sweef nie. Kritiese eksegete neem in hulle Bybelinterpretasie die verkreë kennis op grond van die historiese kritiek (soos onder andere bronne-analise wat te doen het met die vraag na die interafhanklikheid en inhoudelike onderskeidings tussen geskrifte in die Bybel) in ag. In hierdie verband is daar nog baie ander sake wat vir eksegese belangrik is, soos byvoorbeeld die rol wat die bepaalde literatuursoort in kommunikasie vervul, die sosiale kondisionering van die kommunikasie en die belange wat deur die kommunikasie gedien word. Soortgelyke analises behoort toegepas te word rakende die interafhanklikheid van belydenisskrifte, inhoudelike onderskeidings, sosiale kondisionering en die toetsing van belange.

Die erkenning van die realiteit van verskillende konfessionele groeperings onder Christene asook die akkommodering van verskillende beklemtonings in Bybelverstaan 
kom neer op die aanvaarding van 'n sentrum en periferie met betrekking tot die getuienis in die Skrif en die geloof wat geleer word (vgl Loughlin [1997] 1999:53). Tekste in die Bybel en belydenisse in die kerklike tradisie behoort daarom nie bloot naasmekaar in die beskrywing van watter tema ook al te funksioneer nie. Dit kom daarop neer dat daar in interpretasie nie met die uitgangspunt gewerk word dat die betekenis van 'n teks gevind word deur die "betekenisse" van woorde of sinne of temas in die teks (afsonderlik of in samehang met ander tekste in die Bybel as bundel of in die belydenisskrifte as bundel) in 'n somtotaal te hanteer nie. Wat is die verhouding tussen Skrif en die belydenisskrifte in die interpretasie van die geloof wat geleer word? In die Reformatoriese tradisie is die rigting van interpretasie dié vanaf die Skrif na die belydenisskrifte toe en nie vanaf die belydenisskrifte na die Skrif toe nie. My hermeneutiese proses hou rekening met insigte (van Paul Ricoeur - kyk Van Aarde 1999b:437-470) oor die wyse van die ontstaan en ontwikkeling van godsdienstige (belydenismatige) taalgebruik as 'n proses vanaf fundamentele godsdienstige ervaring na metaforiese taalgebruik na geloofsbelydenis. 'n Belydenisskrif is in 'n sekere sin die eindproduk van hierdie proses. Soms word die intensie van die belydenis verwar met die metafoor wat weer met die artikulasie van die grondliggende religieuse ervaring verwar kan word. Byvoorbeeld, die retoriese bedoeling van die tweenatureleer wat histories die beklemtoning van die mensheid van Jesus in die oog gehad het, is onderbou met die ontologiese triniteitsleer wat teruggaan na onder ander die metafoor "Seun van God" wat teruggaan na Jesus se ervaring van God as Vader. Eers as daar 'n onversoende botsing tussen die grondliggende ervaring (uitgedruk met behulp van funksionele metafore) en die retoriese intensie van die geloofsbelydenis (uitgedruk met behulp van ontologiese metafore) aanduibaar is, behoort myns insiens oorweeg te word om 'n nuwe belydenisformule op te stel. Indien so 'n botsing nie aanduibaar is nie, kan die intensie van bestaande formules deur middel van eietydse metafore eksistensieel vertolk word.

\section{DIE BELYDENIS VAN DIE MAAGDELIKE VERWEKKING VAN JESUS}

In die lig van my prinsipiële besinning oor die aard en interpretasie van die geloof wat geleer word, gee ek ten slotte kortliks aandag aan die interpretasie van die geloof wat in 


\section{Besinning oor die interpretasie van die geloof}

die belydenis van die maagdelike verwekking van Jesus geleer word. Daar word in hierdie gedeelte nie orals na substansiërende bronne verwys nie. Die leser wat daarin geinteresseerd is, kan dit in my boek Fatherless in Galilee: Jesus Child of God (Van Aarde 2001) en in my artikel "Dekonstruksie van dogma: 'n Eietydse ondersoek na die spore van die leer van die twee nature van Jesus" (Van Aarde 1999b:437-470) nagaan.

Ek interpreteer die wyse waarop die geboorte van Jesus in die Bybel en in die belydenisskrifte verwoord is, as produkte van voorwetenskaplike denke. Ek sê dit omdat die kritiese en historiese Bybelwetenskap eers tydens die Renaissance en veral ten tye van die kerkhervorming ' $n$ aanvang begin neem het en nie op die Bybelskrywers en die opstellers van die belydenisskrifte 'n invloed kon uitgeoefen het nie. Met die term "voorwetenskaplik" word nie onwetenskaplike, oningeligte of primitiewe denke bedoel nie.

Wat ek in gedagte het, is die feit dat die invloed van die historiese kritiek en die verbysterende ontwikkelinge op die gebied van die natuurwetenskap en tegnologie uiteraard nog nie vir die kerkhervormers en vir diegene voor hulle angeleenthede was waarmee rekening gehou is nie. Soos steeds in sekere wêrelddele vandag, was die voorstelling van 'n maagdelike verwekking vir sowel Grieke as Israeliete nie problematies nie. Hierdie voorstelling skep in der waarheid ook vir baie gelowiges in die Christelike geloofsgemeenskap vandag nie 'n probleem nie. En dit is ook nie my begeerte om dinge wat nie vir mens ' $n$ probleem is nie, vir hulle te problematiseer nie. Ons sal ons egter blind hou as ons nie insien nie dat daar wel heelwat lidmate vandag is wat worstel met vrae oor wat byvoorbeeld vanuit 'n rasionalistiese hoek 'n "ginekologiese onmoontlikheid" genoem is. Sulke worstelvrae word nie altyd uit rebelse kettery gebore nie, maar ontstaan juis as gevolg van 'n veranderde visie op die werklikheid. Hierdie verandering is deur die resultate van die natuurwetenskap meegebring. Daar is dus lidmate wat met opregte bedoelings gewetenskwellings sou hê indien die belydenis van die maagdelike verwekking wat spruit uit die voor-natuurwetenskaplike periode, op dieselfde wyse verwoord sou bly as wat ons dit in die Bybel of in die belydenisskrifte aantref. Dit is tog nie die kulturele leefwêreld van of die Bybel of die kerkhervorming wat voorwerp van geloof behoort te wees nie! Ons vertroue is gerig op God wat Godself in die evangelie bekend maak. 
Hierdie probleem word vererger deur die aansprake van diegene wat op 'n neerhalende wyse mitiese vertellings soos dié oor die belydenis van die maagdelike verwekking as 'n produk van "primitiewe" godsdienstigheid beskou (bv liberale denkers van die agtiende en negentiende eeu soos Pierre Bayle, Bernard le Bovier Fontenelle, Charles de Brosses, Baron d'Holbach, David Hume en Thomas Paine - kyk Duling 1979:139-143). Ek tel nie onder diegene nie. Omdat hierdie tipe oortuiging (rakende wonderbaarlike verwekkings en geboortes) buite die gangbare en natuurlike val, is dit ook vir diesulkes as moderne mense onaanvaarbaar. Ander meen weer dat elke uitspraak in of die Bybel of die belydenisskrif "geglo" moet word soos wat geloofwaardige getuienis wat in 'n hof gelewer word, "geglo" kan word. Waarskynlik is die Duitse Nuwe-Testamentikus, Gerd Lüdemann, ' $\mathrm{n}$ hedendaagse eksponent van hierdie oortuiging. In die Engelse vertaling van sy boek Jungfrauengeburt? Die wirkliche Geschichte von Maria und ihrem Sohn Gottes lees ons onder andere die volgende:

A faith is confessed in the church, the main elements of which have been refuted historically once and for all. From the birth of Jesus from a virgin to his alleged resurrection from the tomb. In the long run it is an intolerable situation for believers to be robbed of their historical foundation and to be allowed to understand everything only in a figurative sense, while nevertheless repeating the creed word for word every Sunday. Here we need a fundamental remedy which overcomes the present state of hypocrisy and creates a viable foundation. The presupposition is dead and that all the attempts to revive the foundations of faith mentioned above are in vain.

(Ludemann [1997] 1998:xvii)

Ook tel ek nie onder die historiste nie. Getuienis van geloof word by hulle verwar met 'n gekontroleerde, geobjektiveerde eksaktheid. In die kerk is daar egter van 'n ander soort "glo" sprake as in 'n hof. Daarom kan godsdienstige mense dinge glo wat nie in die normale gang van die lewe gebeur nie en nie in 'n hof gekontroleer sou kon word nie. Hieronder kan genoem word die verskynsel dat maagde kinders baar. Mense wat hierdie dinge op dieselfde vlak as "gekontroleerde, geobjektiveerde eksakthede" ag, gebruik dik- 
wels buite verband die voorbeeld dat ' $n$ mens in sulke gevalle maar net soos ' $n$ kind moet glo. In sulke gevalle kom om te glo neer op aanvaarding, selfs al eis dit die opoffering van die intellek.

Beide oordele, dié van die "hovaardige rasionalis" en dié van die "kinderlike gelowige", dikwels sonder dat dit besef word, gaan gebuk onder die natuurwetenskaplike invloed wat ' $n$ empiristiese houding meebring dat sien glo is. Laasgenoemde is van mening dat "objekte" buite ons, die getuies wat die Bybelse verhale opgeteken het, wel die bonatuurlike dinge wăarvan die Bybel praat, "gesien" het en daarom moet ons vandag dit eenvoudig soos 'n kind "glo". Die opstellers van die belydenisskrifte is vir diegene voorbeelde van mense wat hulle "geloof" in "volkome" ooreenstemming met dié van die getuies in die Bybel verwoord het. Wat word hier nie in ag geneem nie? Die feit dat beide die opstellers van die belydenisskrifte en die getuies in die Bybel die natuurwetenskaplike en histories-kritiese beïnvloeding nie meegemaak het nie. Met ander woorde, die feit dat die verwoordings in die Bybel en in die belydenisskrifte voortgekom het uit 'n vroeëre tydraamwerk. Vervolgens, dat hierdie tydraamwerk reeds deur twee ander opeenvolgend agterhaal is. Om aan te dring dat vroeëre verwoordings in normatiewe geskrifte onder alle omstandighede onbevraagtekend aanvaar moet word, kom neer op die "glo" van dit wat ander "glo", dit wil sê die glo van geloofsproposisies. Hoewel die belydenistradisie vir my belangrik is, meen ek dat geloof in die eerste plek op ' $n$ verhouding met God behoort te dui. Die teologiebeoefening wat die "geloof in proposisies" ondersteun, het noodwendigerwys 'n bevestigende funksie en nie 'n ondersoekende en bevraagtekende een nie. Die Bybel funksioneer in so ' $n$ teologie bloot as die bron van waaruit bewyse van gevestigde en gepatenteerde geloofsartikels opgediep word. Die kerkhervorming en die opkomende Bybelwetenskap het egter per definisie van so 'n Bybelgebruik afgestap.

Wanneer ons probeer vasstel wat die geloof is wat in die belydenis van die maagdelike verwekking van Jesus geleer word, soos dit in die belydenisskrifte verwoord is, sien ons dat dit glad nie gaan om geloof wat in waarneembaarheid of in historisiteit as sodanig gegrond is nie. Hoe sou dit dan kon? Ons het mos gesien dat hierdie soort kwessies nie in die tyd toe of die Bybel of die belydenisskrifte geskryf is, saak gemaak het nie. Vandag is ons mense geneig om vanweë ons empiriese denke die krag van 
hierdie belydenis vas te maak aan die feitelikheid al dan nie van Jesus se buitengewone verwekking. "Feit" beteken in hierdie verband factum brutum, iets wat kontroleerbaar werklik sou gebeur het. Indien die verskillende berigte in die Nuwe Testament op hierdie wyse, op soek na kontroleerbare eksakthede, geinterpreteer sou word, sal daar gou gestuit word voor vrae soos: wie is nou empiries reg Paulus of Lukas? Matteus of Johannes? Die getuienis is histories en empiries gesien, uitsluitend van aard.

Net soos die belydenis van die opstanding reeds vroeg aan die begin van die tweede eeu na Christus deur die kerkvader van Antiogië, Ignatius, ingespan is om die belydenis "Jesus is God" te onderbou, het dieselfde met betrekking tot die geboorte van Jesus Christus gebeur. Sover ons kennis strek, was dit Ignatius wat vir die eerste keer die geboortevertelling in die Matteusevangelie eksplisiet as 'n maagdelike verwekking geinterpreteer het. Ons moet egter daarteen waak om dit wat latere getuies gesê het, in dit wat vroeër gesê is, in te lees. So 'n tipe benadering sou op "inleg" neerkom en nie op "uitleg" nie. Ook moet ons daarteen waak dat die voortgang van die ontwikkeling van 'n bepaalde belydenis nie tot absurditeite lei en dat die belydenis konteksloos in die lug begin hang, terwyl die leer (die retoriese intensie) wat daarin vervat is, ontkragtig word nie. Hierdie gevaar het werklik ernstige afmetings in veral die Rooms-Katolieke Kerk aangeneem en dit het tot onaanvaarbare Maria-verering en selfs tot Maria-vergoddeliking gelei. Hierdie oortuiging het die grondliggende religieuse ervaring wat teruggaan na Jesus self toe, verlaat en dit het eerder 'n verhindering van belydenis van geloof geword.

Die vroegste getuies in die Nuwe Testament, Paulus en Markus, ken nie 'n maagdelike verwekking van Jesus nie. Alleen die Matteus- en die Lukasevangelie het die geboorte van Jesus in hulle vertellings oor Jesus opgeneem. Ons het gesien dat Ignatius die geboortevertelling in die Matteusevangelie eksplisiet as 'n maagdelike verwekking geïnterpreteer het. Sy motief was om die gnostiese dwaling te weerlê dat God nie met verwerplike mensheid verenig nie. In die tweede eeu bely onder andere die kerkvader Origenes ook die maagdelike verwekking. Dit het hy gedoen teen die agtergrond van onaanvaarbare oortuigings dat die familie van Jesus na bewering aanspraak daarop sou maak dat Jesus 'n Jood vir slegs Jode sou wees. Met die belydenis van Jesus se verwekking deur die Vader wou Origenes beklemtoon dat Jesus betekenis het vir die ganse mensdom, want God kan nie binne die grense van die Jodedom ingeperk word nie 
(kyk Brown 1973). Terselfdertyd is daar met die belydenis van die maagdelike verwekking wal gegooi teen 'n toenemende afwykende gedagte dat God nie woning wil maak in nietige mensheid nie. Juis daarom het die belydenis van die maagdelike verwekking gedurende die tweede eeu 'n voorwerp van bespotting vir sekere Griekse filosowe geword dat Christene hulleself sou anmatig deur te beweer dat God se Seun vanuit 'n nederige kleinboerderygemeenskap soos Nasaret kan kom (kyk Cook 2000:2829). Spore van 'n reaksie op 'n soortgelyke verleentheid kan reeds in die Evangelie van Johannes gesien word (vgl Ludemann 1998:127-134).

In die Matteusevangelie word die nederigheid van Jesus se herkoms egter nie as ' $n$ verleentheid gesien nie. Matteus sluit daarom by die profeet Miga aan wat praat van die geboorte van 'n koningskind in die geringe Betlehem en nie in die magtige Jerusalem nie. Dit is hierdie koningskind, in aansluiting by die profeet Jesaja, wat God-by-ons is, en nie Herodes die Grote wat deur die keiser van Rome as "koning van die Judeërs" verklaar is nie. Matteus bou veral voort op temas wat bekend was in die HellenistiesSemitiese literatuur van die eerste eeu na Christus (bv Pseudo-Philo se Liber Antiquitatum Biblicarum). Hierdie temas hou verband met oortuigings dat Moses se geboorte van Goddelike ingrype getuig. In sekere van hierdie dokumente is daar ten opsigte van Moses selfs sprake van 'n "Goddelike verwekking" (bv b Baba Batra 120a; Eks Rab 1:13, 19 - kyk Van der Horst 1978:358) en dat, na aanleiding van onderskeidelik Eksodus 7:1 en Eksodus 4:16, Moses "God" vir Farao en vir die volk ( $\mathrm{d}$ v Aäron) bemiddel het (kyk Meeks 1970:354-371). In die Matteusevangelie funksioneer Moses op 'n baie duidelike wyse as 'n tipe van Jesus (kyk Crossan 1986:18-27; Allison 1993:140). In die Lukasevangelie word die geboorte van Jesus, verwek deur die Gees van God, gestel teenoor die geboorte van die keiser van Rome, Augustus (vir parallelle tussen Lukas en die GrieksRomeinse mitologie en Romeinse keiserkultus, vgl ook Van Tilborg \& Counet 2000:200264). Augustus, 'n aangenome seun van Julius Caesar, se eie herkoms is teruggevoer na 'n goddelike geboorte volgens die godeverhale wat kom uit die legendes van die Juliusfamilie (kyk Klauck [1995/1996] 2000:289-302). Augustus het ook sy eie verjaarsdag as 'n "evangelie" beskryf en hy het homself as 'n god verklaar wat vereer moet word as die "redder van die wêreld". In die Lukasevangelie word Jesus se geboorte en die betekenis daarvan egter as sodanig beskryf. 
Wat nêrens in die Nuwe Testament gebeur nie, het by Ignatius plaasgevind toe hy sy verstaan van die maagdelike verwekking van Jesus Christus in verband gebring het met die gedagte van preëksistensie en inkarnasie (kyk sy briewe aan die Efesiërs 18:2, die gemeente in Smirna 1:1 en aan die Tralliërs 9:1). Hierdie gedagte is wel in die Johannesevangelie (en in ' $n$ sekere sin ook by Paulus) aanwesig, maar nie in of Lukas se vertelling oor Jesus se maagdelike verwekking of Matteus se vertelling oor Jesus se Goddelike verwekking nie. Die ontwikkeling by Ignatius, waarvan daar spore in die Johannesevangelie is, het antidoketiese motiewe, sowel as om die sondeloosheid van die Messias te beklemtoon. Die feit dat veral Thomas van Aquino gedurende die Middeleeue die virtus van die Heilige Gees (in onderskeid van die substantia van die Vader) in die verwekking van die Messias beklemtoon het (kyk Brown 1973), is 'n aanduiding daarvan dat die Triniteitsleer die verwysingsraamwerk begin vorm het waarbinne die maagdelike geboorte van Jesus geinterpreteer is. Laasgenoemde ontwikkeling vorm die belangrikste agtergrond van die geloofsoortuiging met betrekking tot die belydenis van die maagdelike verwekking soos dit in die Reformatoriese belydeniskrifte tot uitdrukking gebring is.

Op die keper beskou vorm die "twee nature" leer die grondslag van die Reformatoriese interpretasie van die maagdelike verwekking van Jesus en veral die beklemtoning van die ware mensheid van Jesus. Die Heidelbergse Kategismus (35) formuleer hierdie dogma soos volg (NHKA Diensboek 1993:177):

\footnotetext{
Wat beteken: wat ontvang is van die Heilige Gees, gebore is uit die maagd Maria? Dat die ewige Seun van God, wat ware en ewige God is (a) en (b) bly, die ware menslike natuur uit die vlees en bloed van die maagd, Maria (c), deur die werking van die Heilige Gees aangeneem het (d). So is Hy tegelykertyd die ware nakomeling van Dawid (e), in alles aan sy broers gelyk (f), behalwe die sonde ( $(\mathrm{g})$.
}

In hierdie beklemtoning het die Protestante en die Rooms-Katolieke nie van mekaar verskil nie. Beide teken apologie an teen die anti-trinitariese strominge van hulle tyd (bv die Socciane). 'n Aspek van die bedoeling van die Nederlandse Geloofsbelydenis (Art 18) se formulering kan selfs geïnterpreer word (soos in ander gevalle in hierdie belydenisskrif) as 'n bewustelike konformering met die Rooms-Katolieke leer 
(NHKA Diensboek 1993:143-144): "Ons bely dat God ... sy eniggebore en ewige Seun in die wêreld (ge)stuur (het) .... Hy het ... werklik 'n egte menslike natuur ... aan (ge)neem ... $\mathrm{Hy}$ is in die liggaam van die geseënde Maria deur die krag van die Heilige Gees [kyk weer Thomas Aquinas] en sonder toedoen van 'n man verwek ...."

Die agtergrond van die bedoeling om deur middel van die NGB by die RoomsKatolieke Spaanse heerser (Filips II) van die Nederlande in die nag van 1/2 November 1561 te pleit dat hy moet ingryp om die godsdienstige vervolging van die Calviniste te staak, is goed bekend. Dit is ook bekend dat pous Paulus IV enkele jare gelede die dekreet (as apologie teen die anti-trinitariers) van die altyd-maagdskap van Maria uitgevaardig het. Hiervoor het hy hom op die tradisie beroep wat sedert die tweede eeu in apokriewe geskrifte (kyk Schaberg 1994:708-727) en in die apologetiese geskrifte van kerkvaders (bv Origines en Justinus - kyk Cook 2000:28-31) gevind word en waarin beweer word dat Josef nie seksuele gemeenskap met Maria gehad het nie.

Hierdie dogma (net soos dié in die NGB) doen 'n beroep op Johannes 1:13. Eksegeties gesien, sê hierdie teks (net soos Joh 3:5-7) dat kinders wat uit God "opnuut"/ "van bo" gebore is, naas 'n natuurlike geboorte ook 'n geestelike geboorte het. Daar kan geredeneer word dat daar met reg die afleiding gemaak kan word dat daar by God se kinders van "twee nature" sprake is. Hierdie oortuiging word ook by Paulus aangetref dat Jesus die "broer" van gelowiges is. Paulus onderskei egter ook tussen Jesus en die gelowiges met die gedagte van Jesus as die "eersgeborene". Hierby sluit die NGB aan met die uitdrukkings "eniggebore en ewige Seun", maar anders as by Paulus (en Johannes) word dit in ontologies-metafisiese terme geartikuleer. Die "leer" uitgedruk in hierdie belydenis is dat die verlossing by Jesus Christus te vind is (soos dit gesien kan word in sowel die tweede deel van NGB 18 as NGB 19). Die NGB is ook gerig teen die herlewing van die (gnostiese) anti-doketiese oortuigings soos dit by die Anabaptiste aangetref is.

Hoewel ons nie al hierdie aspekte meteen reeds in die vroegste getuies, soos Paulus en Markus, kan inlees nie en ook nie hierdie getuies kan laat sê wat eers later bely is nie, kan ek nie anders as om instemming te toon met die saak wat ten grondslag van die belydenis van die maagdelike verwekking lê nie. Die vraag of hierdie belydenis steeds deel van ons belydende lewe vandag moet wees, hang vir my nie daarvan af of daar 
"bewyse" daarvoor in die Heilige Skrif gevind kan word of nie. Die Heilige Skrif is immers nie in die eerste plek bedoel om te dien as 'n handboek van "teksbewyse" van onveranderlike leerstukke nie. Die Heilige Skrif is die bron van die viva vox, die lewende stem van God wat in en deur die kerk verkondig word. Om die "leer" wat in die belydenis van die maagdelike geboorte uitgedruk is, steeds vandag te bely hang ook nie daarvan af of dit vir moderne mense vandag met die verstand bewysbaar is of nie. Die vraag is of die "hart" van hierdie belydenis deel van die evangelie is of nie. En dit, meen ek, is wel die geval: God het en maak nog steeds woning by nietige en hulpelose mense wat weet hoe afhanklik hulle van God is; God verhoog die nederige en verneder die hoogmoedige; God het die wêreld oneindig lief; God tref geen onderskeid tussen persone en groepe nie; God maak Godself vir ons in Jesus, vir ons Christus en Here, bekend; God se koninkryk is kwalitatief radikaal anders as aardse koninkryke.

\section{Literatuurverwysings}

Allison, D C 1993. The New Moses: A Matthean typology. Minneapolis, MN: Fortress.

Borg, M J 1991. Portraits of Jesus in contemporary North American scholarship. HTR 84, 1-22.

Borg, M J [1994] 1995. Als met nieuwe ogen: De historische Jezus en waar het op aan komt in het geloof vandaag, vertaal deur Peter Ros. Zoetermeer: Meinema.

Brown, R E 1973. The virginal conception \& bodily resurrection of Jesus. New York: Paulist Press.

Bultmann, R 1933. s v á $\lambda \hat{\theta} \theta \varepsilon ı \alpha$. Theologisches Wörterbuch zum Neuen Testament, Band I, 239-251. Stuttgart: Kohlhammer.

Cook. J G 2000. The interpretation of the New Testament in Greco-Roman paganism. Tubingen: Mohr Siebeck. (Studien und Texte zu Antike und Christentum.) Crenshaw, J L 1981. Old Testament wisdom: An introduction. Atlanta, GA: John Knox. Crossan, J D 1986. From Moses to Jesus: Parallel themes. Biblical Review 2(2), 18-27.

- 1998. The birth of Christianity: Discovering what happened in the years immediately after the execution of Jesus. San Francisco, CA: HarperSanFrancisco.

Douglas, M 1966. Purity and danger. London: Routledge \& Kegan Paul. 
Dreyer, Y 2000. Institutionalization of authority and names used for Jesus. PhDproefskrif, Universiteit van Pretoria.

Duling, D C 1979. Jesus Christ through history. New York, NY: Harcourt Brace Jovanovich.

Ellingworth, P 1994. Christology: Synchronic or diachronic?, in Green, J B \& Turner, M (eds), Jesus of Nazareth: Lord and Christ. Essays on the historical Jesus and New Testament Christology, 489-500. Grand Rapids, MI: Eerdmans.

Fuchs, E 1962. s v Wahrheit. Die Religion in Geschichte und Gegenwart, Sechster Band, 1515-1517. Tubingen: J C B Mohr (Paul Siebeck).

Funk, R W \& Hoover R W (and The Jesus Seminar) 1993. The Five Gospels: The search for the authentic words of Jesus. New York: Macmillan Publishing Company. (A Polebridge Book.)

Holmberg, B 1978. Paul and power: The structure of authority in the primitive church as reflected in the Pauline epistles. Lund: CWK Gleerup.

Käsemann, E 1963. Paulus und der Frühkatholizismus. ZThK 60, 75-98.

Katz, S T 1984. Issues in the separation of Judaism and Christianity after 70 CE: A reconsideration. $J B L 103,43-76$.

Klauck, H-J [1995/1996] 2000. The religious context of early Christianity: A guide to Graeco-Roman religions, tr by B McNeil. Edinburgh: T \& T Clark.

Lemmen, M M W 1990. Max Weber's sociology of religion: Its method and content in the light of the concept of rationality. Hilversum: Uitgeverij Gooi en Sticht.

Loader, J A 1979. Polar structures in the book of Qohelet. Berlin: De Gruyter. (Beiheft zur ZAW 152.)

Loughlin, G [1997] 1999. The basis and authority of doctrine, in Gunton, C E (ed), The Cambridge companion to Christian doctrine, 41-64. Cambridge, UK: Cambridge University Press.

Ludemann, G [1997] 1998. Virgin birth? The real story of Mary and her son Jesus, tr by J Bowden. Harrisburg, PA: Trinity Press International.

McGrath, A E 1990. The genesis of doctrine: A study in the foundation of doctrinal criticism. Grand Rapids, MI: Eerdmans. 
Meeks, W A 1970. Moses as God and King, in Neusner, J (ed), Religions in antiquity: Essays in memory of Erwin Ramsdell Goodenough, 354-371. Leiden: Brill.

Mödritzer, H 1994. Stigma und Charisma im Neuen Testament und seiner Umwelt: Zur Soziologie des Urchristentums. Göttingen: Vandenhoeck \& Ruprecht. (Novum Testamentum et Orbis Antiquus 28.)

Nederduitsch Hervormde Kerk van Afrika [NHKA] 1993. Diensboek. Vierde hersiene uitgawe. Pretoria: KITAL.

Nederduitsch Hervormde Kerk van Afrika [NHKA] 1997. Kerkorde, gewysig volgens besluite van die 65ste Algemene Kerkvergadering. Pretoria: NHKA.

Neusner, J 1973. The idea of purity in ancient Judaism. Leiden: Brill.

Neyrey, J H 1990. Paul in other words: A cultural reading of his letters. Louisville, KT: Westminster.

Quell, G 1933. s v Der at.liche Begriff אמחת. Theologisches Wörterbuch zum Neuen Testament, Band I, 233-237. Stuttgart: Kohlhammer.

Saler, B 1977. Supernatural as a Western category. Ethos 5, 31-53.

Schaberg, J 1994. The infancy of Mary of Nazareth (Proto-James and Pseudo-Matthew), in Schüssler Fiorenza, E (ed), For searching the Scriptures, Volume II: A feminist commentary, 708-727. New York: Crossroad.

Schleiermacher, F [1806] [1827] 1843. Die Weinachtsfeier: Ein Gespräch, in Friedrich Schleiermacher's Sämmtliche Werke, Erste Abtheilung: Zur Theologie, Erster Band, 461-525. Berlin: G Reimer.

Schlier, H 1957. Der Brief an die Epheser: Ein Kommentar. Duisseldorf: Patmos-Verlag. Schmid, H H 1966. Wezen und Geschichte der Weisheit. Berlin: Töpelmann.

- 1968. Gerechtigkeit als Weltordnung. Tübingen: Mohr-Siebeck.

- 1973. Schöpfung, Gerechtigkeit und Heil. ZThK 70, 1-19.

Schulze, L F 1994. Die teologiese wortels en struktuur van die Heidelbergse Kategismus. HTS 50, 194-210.

Thiselton, A C 1980. The two horizons: New Testament hermeneutics and philosophical descriptions with special reference to Heidegger, Bultmann, Gadamer, and Wittgenstein. Exeter: Paternoster. 
Thiselton, A C 1992. New horizons in hermeneutics: The theory and practice of transforming biblical reading. London: HarperCollins.

- 1994. Christology in Luke, speech-act theory, and the problem of dualism in Christology after Kant, in Green, J B \& Turner, M (eds), Jesus of Nazareth: Lord and Christ. Essays on the historical Jesus and New Testament Christology, $453-$ 472. Grand Rapids, MI: Eerdmans.

Tuckman, B W 1965. Developmental sequence in small groups. Psychological Bulletin 63, 384-399.

Van Aarde, A G 1999a. Wat is waarheid? 'n Teologiese antwoord van 'n Bybelwetenskaplike, in Van Wyk, D J C (red), 20 ste eeu Hervormde teologie, 11-27. Pretoria: SENTIK.

- 1999b. Dekonstruksie van dogma: 'n Eietydse ondersoek na die spore van die leer van die twee nature van Jesus. HTS 55(2\&3), 437-470.

- 2001. Fatherless in Galilee: Jesus Child of God. Harrisburg, PA: Trinity Press International.

Van der Horst, P W 1978. "Seven months" children in Jewish and Christian literature from antiquity. EThL 54, 346-360.

Van Tilborg, S \& Counet, P C 2000. Jesus' appearances and disappearances in Luke 24. Leiden: Brill. (Biblical Interpretation Series.)

Weber, M [1947] 1968. Max Weber: On charisma and institution building. Selected papers edited and with an introduction by E N Eisenstadt. Chicago: University of Chicago Press.

Witherington, B 1994. Jesus the sage: The pilgrimage of wisdom. Minneapolis, MN: Fortress. 